\title{
A Longitudinal Study on the Psycho-Sociological Impact of COVID -19 Lockdown on College Students \& Faculty
}

Augustin Joseph has been an educator and educational administrator for over a decade. Currently he is pursuing $\mathrm{PhD}$ in educational leadership.

James Molekunnel Chacko is a Clinical Psychologist and practicing Counselor. He is HoD of Psychology, PG Coordinator and Associate Professor at Salesian College, Siliguri.

Paramita Datta, Associate Professor, Department of Psychology, Salesian College Siliguri. She is the affiliate member of American Psychological Association \& Associate member of Indian Psychiatric Society.

Patrick Johnson teaches in the Department of Management, Salesian College, Siliguri.

Rachel Salomit Sitling is the Head of Department of Sociology at Salesian College, Siliguri Campus. She has a B.A degree in History and a Master degrees in Sociology and History

Sumina Chettri, Assistant professor, Head of the department of BSW, Member of the board of BSW, Member of the exam committee.

\section{Abstract}

As we are travelling through the ambiguous viral times, the papers attempts for a preliminary assessment of the fear and anxiety among the faculty and students of Salesian College. From the data accumulated through a series of online questionnaires, the paper analyses the impact of the lockdown on a diverse range of indicators - that includes boredom, aspects of the future, sociality conducted with a group of faculty and students of the college.

Keywords: Pandemic, Salesian College, psycho-social impact, boredom, anxiety. 
A Longitudinal Study on the Psycho-Sociological Impact of COVID -19... / 107

Salesian Journal of Humanities and Social Sciences, Vol. XI, No.2 (Dec 2020)

ISSN: 0976-1861 | DOI: 10.51818/SJHSS.11.2020.106-122 | Page: 106-122,

Section: Articles

\section{An Intervention}

Traditionally though being healthy was associated with the ability to perform the tasks assigned to oneself in the family or work environment, a shift has occurred in health coming to beconsidered the balance betweenphysical, mental and social well-being. Probably it goes to the now classical definition by WHO (World Health Organization), "health is a complete state of physical, mental and social wellbeing and not merely the absence of disease or infirmity."1The past few months have added to the familiar world of words new terms that evoke feelings like the pandemic, quarantine, lockdown and social distance. The COVID-19 pandemic is by now rated as one of greatesthealth challenges thehistory of humankind has evercome to face. The pandemic has ravaged the world in more ways than one andchanged lives of individuals and communities in ways that are in some sense irreversible. COVID-19 believed to have started off on December 2019 at Wuhan city of central Hubei province of China, ${ }^{2}$ is by now a global phenomenon that defies the logic of time and space.

It was on $11^{\text {th }}$ January2020 that China announced its first Covid-19 related death. ${ }^{3}$ Within a couple of weeks the infection had recorded a spreadacross the globe at an alarming pace. ${ }^{4}$ By the timeon $11^{\text {th }}$ March 2020 when WHO declared COVID-19 to be a pandemic it was recorded to have reached about 114 countries. ${ }^{5}$ The arrival of ${ }^{1} \mathrm{WHO}$,

https:/ / www.who.int/about/who-we-are/constitution\#: :text=Health\%20is\%20 a $\% 20$ state $\%$ 20of,belief $\% 2$ C $\% 20$ economic $\% 20$ or $\% 20$ social\%20condition.

2 M.L. Holshue et.al., "First case of Novel Corona virus in the United States"New EnglandJournalofMedicine382, 10(2020): 929-936. Retrieved fromhttps://doi. org/10.1056/NEJMoa2001191.

${ }^{3}$ WHO, "Pneumonia of Unknown Cause- China," 2020. Retrieved from https:// www.who.int/csr/

${ }^{4}$ WHO, "Coronavirus Disease 2019 (COVID-19)", Situation Report- 46, 2020. Retrieved from

https://www.who.int/docs/default-source/coronavirus/situationreports/20200306-

${ }^{5}$ WHO, "Rolling Updates on Corona virus Disease (COVID-19)," 2020. Retrieved fromhttps:/ / www.who.int/emergencies/diseases/novel-coronavirus-2019/ events-as-they-happen. 
108 / Augustin Joseph, James Chacko Molekunnel, Paramita Datta, Patrick Johnson, Rachel Salomit Sitling \& Sumina Chettri

Salesian Journal of Humanities and Social Sciences, Vol. XI, No.2 (Dec 2020)

ISSN: 0976-1861 | DOI: 10.51818/SJHSS.11.2020.106-122 | Page: 106-122,

Section: Articles

the virus marked the spread of fear and near trauma associated with thelargenumber of deaths it was leaving behind, in more than one country and especially among the elderly.On 23rd March 2020the tally of people who died from COVID-19 stood at 14, 509 and rising. ${ }^{6}$

COVID-19 is found to be highly contagious and spreads at a very rapid pace with the longevity of the virus deposited on surfaces contaminated for nearly a week. This omnivorous coronavirus hit India in March 2020. The dreadful nature of this pandemic made one numb and it's high fatality rate created universal psychosocial impact in the form of mass hysteria, and it had directand indirectimpact on the economic uncertainty that loomed large for a vast majority of the population. People panicked and started behaving strangely as 'coronaphobia' generated a plethora of psychosocial manifestations across every corner of society. The rapidmode in which hysteria and panic spread regarding COVID-19 could beget enduring psychological impact on the public - even more than the socio-economic domains - which could potentially be more detrimental in the long run. ${ }^{7}$ In order to, supposedly, combat the disease and to prevent the spread of infection Government of India imposed a lockdown on $24^{\text {th }}$ March 2020. People were forced to stay at home. The social fabric of India thrives on interdependence - both emotional and economic - within the families, relatives and friends. ${ }^{8} \mathrm{Close}$ physical interactions like living in crowded housing and other places necessitates pushing and jostling which are extremely common and are a deterrent to 'social-distancing' as mandated during the pandemic. ${ }^{9}$ The economic impact of this pandemic on India includes increase in poverty - pushing more people below poverty

${ }^{6} \mathrm{WHO}$, "Corona virus disease 2019 (COVID-19)", Situation Report - 63, 2020.

${ }^{7}$ A. Depoux et.all., "The pandemic of social media panic travels faster than the COVID-19 outbreak," Journal of Travel Medicine 27, 3(2020).

${ }^{8}$ D. Jacobson, "Indian Society and ways of living," Asia Society,2020.Retrieved fromhttps:/ / asiasociety.org/education/indian society-and-ways-living.

${ }^{9}$ H.S. Gopalan andA. Misra, "COVID-19 pandemic and challenges for socioeconomic issues, healthcare and National Health Programs in India",Diabetes Metabolic Syndrome: Clinical Research and Reviews14, 5( 2020): 757-59.Retrieved from https://doi.org/10.1016/j.dsx.2020.05.041 
A Longitudinal Study on the Psycho-Sociological Impact of COVID -19... / 109

Salesian Journal of Humanities and Social Sciences, Vol. XI, No.2 (Dec 2020)

ISSN: 0976-1861 | DOI: 10.51818/SJHSS.11.2020.106-122 | Page: 106-122,

Section: Articles

line ${ }^{10}$ resulting in the worsening of socio-economic inequalities. ${ }^{11}$ It becomes a truism that as a consequence the people have become more prone to psychological distress during the pandemic. ${ }^{12}$

It has affected almost all the individuals in the society.It is alsoevinced that students, teachers, andresearchers havenot been excluded from registering some levels of stress and anxiety. One set of existing literature focussing on these groups within society argues that special attention should be diverted to them on account of the potentiallyhigher psychological distressrelated impact experienced by them. ${ }^{13}$ The longitudinal study presented here is an attempt by Salesian College to uncover the mental, emotional and physical reactions of the students and the faculty to the lockdown during COVID-19 pandemic with an intent to map and understand to some extent the social impact of the same.

\section{The Mode, Material and Method}

As stated above the objective of the study, therefore, was to understand the mental, emotional and physical reactions of the students and the faculty of Salesian College to the lockdown during COVID-19 pandemic as well as its social impact.

It was a 4 week observational longitudinal study which started on $28^{\text {th }}$ March 2020 and ended on $24^{\text {th }}$ April 2020. The participants were selected usingSnowball sampling techniquethrough anonline survey. Total 612 students and 97 faculty participated in the $1^{\text {st }}$

\footnotetext{
${ }^{10}$ M.K. Anser et.all, "Does Communicable Diseases (including COVID-19) may increase global poverty risk? A cloud on the Horizon," Journal of Environmental Research 187, 2020. Retrieved from https:/ / doi: 10.1016/j.envres.2020.109668.

11 S. Mahendra Dev,"Addressing COVID-19 Impacts onAgriculture, Food SecurityandLivelihoods in India," IFRI: InternationalFood Policy ResearchInstitute, 2020 Retrievedfromhttps:// www.ifri.org/blog/addressing-COVID-19-impactsagriculture-food-security-and-livelihoods-india.

${ }^{12}$ U. Rehman et.all., "Depression, Anxiety and Stress AmongIndians in Times of Covid-19 Lockdown," Community mental health journal, 2020:1-7.Advanced online publication. https://doi.org/10.1007/s10597020-00664-x

${ }^{13}$ Ibid.
} 
week; 642 students and 82 faculty participated in the $2^{\text {nd }}$ week; 474 students and 77 faculty participated in the $3^{\text {rd }}$ week; 346 students and 92 faculty participated in the $4^{\text {th }}$ week. The link of the questionnaire was sent through Google forms, LMS Moodle (an in house learning management system) platform of the college ${ }^{14}$ and by emails to the faculty and students of Salesian College, Sonada and Siliguri.On receiving and clicking the link the participants got auto directed to the information about the study. First, they filled up the demographic details and then a set of questions appeared sequentially which the participants were to answer. Consent was sought and taken separately from allthe participants.

The online self-reported questionnaire developed by investigators was divided into two sections: a) demographic details, b) opinion regarding COVID-19 lockdown. Section b) had 20 questions which the participants were to rate on 5 point scale from completely agree to completely disagree.

SPSS 25 was the tool used for statistical analysis. Descriptive statistics has been used in this study to analyse the findings.

\section{Pandemic Perceptions}

This section brings together the selective summary of the data assessed from the questionnaire answered by the participants over the weeks both as descriptive analysis as well as in graphic format. The first sub section contains the selected 7 questions out of the 20 questions on which the student responses had a significant impact statement to make. The second subsectioncontains similarly the four questions out of the 20 based on which an indirect assumption could be drawn regarding the psycho-social impact under study.

\section{The Student Data}

As mentioned earlier, number of students who participated in week 1 were 612, week 2 were 642, week 3 were 474 and week ${ }^{14}$ Learning and Management Software (LMS). 
A Longitudinal Study on the Psycho-Sociological Impact of COVID -19... / 111

Salesian Journal of Humanities and Social Sciences, Vol. XI, No.2 (Dec 2020) ISSN: 0976-1861 | DOI: 10.51818/SJHSS.11.2020.106-122 | Page: 106-122,

Section: Articles

4 were 346 . The mean age of students was $19.67( \pm 1.58)$ years.

Majority of students felt bored during lockdown. This claim is substantiated by the findingsthat show $17.8 \%$ of students in week 1 completely agreeing and $39.2 \%$ agreeing to the proposition posed to them. During week 2 , the responses to agree and completely agree, in this regard, were $40.7 \%$ and $13.7 \%$ respectively. During week 3 , the figures continued to be $40.3 \%$ and $14.8 \%$ as those who agreed and completely agreed with regard to feeling of boredom. In the last week instead, those who agree decreased to $35.5 \%$ and completely agree increased to $16.8 \%$. On the other hand, students who during the same time recorded $24.5 \%, 26.9 \%, 25.7 \%$ and $28.3 \%$ for Week 1 , Week 2, Week 3 and week 4 as having disagreed with the question. There has been a gradual fall in students response from those who were undecided from $14.1 \%$ (week1), 12\%(week 2), to 12\% (week3) to $12.7 \%$ (W4).It is evident from the responses that students were anxious about their family and future. For all the 4 weeks, agree and completely agree were high i.e. in week $1,48 \%$ and $27.6 \%$, during week 2, $48.9 \%$ and $23.1 \%$, and week $3,47.5 \%$ and $25.1 \%$, in week $449.7 \%$ and $23.4 \%$ respectively. As opposed to this only a small percentage of respondents i.e. $2.61 \%$ (week1), 2.22\% (week 2), $3.01 \%$ (week 3) and $2.60 \%$ (week 4 ) have completely disagreed to the question. The data shows that very few disagree with the question. The undecided responses were $15.7 \%, 14.8 \%, 16.2 \%$, and $15.2 \%$ from week 1 to week 4 respectively. Majority of the students have agreed that they feel good about spending more time with their family in all weeks, i.e. in week 1 completely agree $40.7 \%$ and agree $49.3 \%$, in week $2,38 \%$ (completely agree) and $49.8 \%$ (agree), 33.3\%, 53.8\%, 34.4\% \& 53.8\% respectively in week 3 and 4. The responses indicate that most of the students have been upset due to inability to meet their friends. The percentage of those who agree and completely agree throughout the 4 weeks are $42.8 \%$ and $24 \%$ (week 1), $43.6 \%$ and $17.3 \%$ (week 2), $45.6 \%$ \& $16.7 \%$ (week 3 ) and lastly in week $4,44.8 \%$ and $18.2 \%$. The responses also illustrate that in all the 4 weeks a major percentage of the students have agreed that they are 
112 / Augustin Joseph, James Chacko Molekunnel, Paramita Datta, Patrick Johnson, Rachel Salomit Sitling \& Sumina Chettri

Salesian Journal of Humanities and Social Sciences, Vol. XI, No.2 (Dec 2020)

ISSN: 0976-1861 | DOI: 10.51818/SJHSS.11.2020.106-122 | Page: 106-122,

Section: Articles

unhappy to be forced to abstain from many activities, which they enjoyed. Highest percentagein week $1,42.2 \%$ agree. As the week progresses the responses of the students who agree are $40.8 \%, 37.6 \%$ and $37.3 \%$ respectively. The figures clearly show that the majority of the students have either agreed or completely agreed that they are worried about the economic impact of the pandemic. During week 1 completely agreeand agreeare $29.2 \%$ \& $43 \%$ respectively. The percentage of agree and completely agree in the other weeks are $42.2 \%$ and $27.1 \%$ (week 2), 43.7\% and 24.3\% (week 3) and week 4,43.9\%, 28.3\%. The figures do show us that each week the highest percentage of respondents have agreed on being obsessed with washing hands and using sanitizers, i.e. $45.1 \%, 43.9 \%, 46.6 \%$ \& $45.7 \%$ respectively. Students are agreeingthat they are anxious in mixing with others. 39.5\% have agreed in week 1 and $37.9 \%, 38.6 \%$ and $37.3 \%$ have agreed respectively in the other 3 weeks.

\section{The Faculty Data}

The total number of faculty who participated in week 1 were 97 , week 2 were 82 , week 3 were 77 and week 4 were 92 . The mean age of faculty was $30.17( \pm 9.25)$ years.

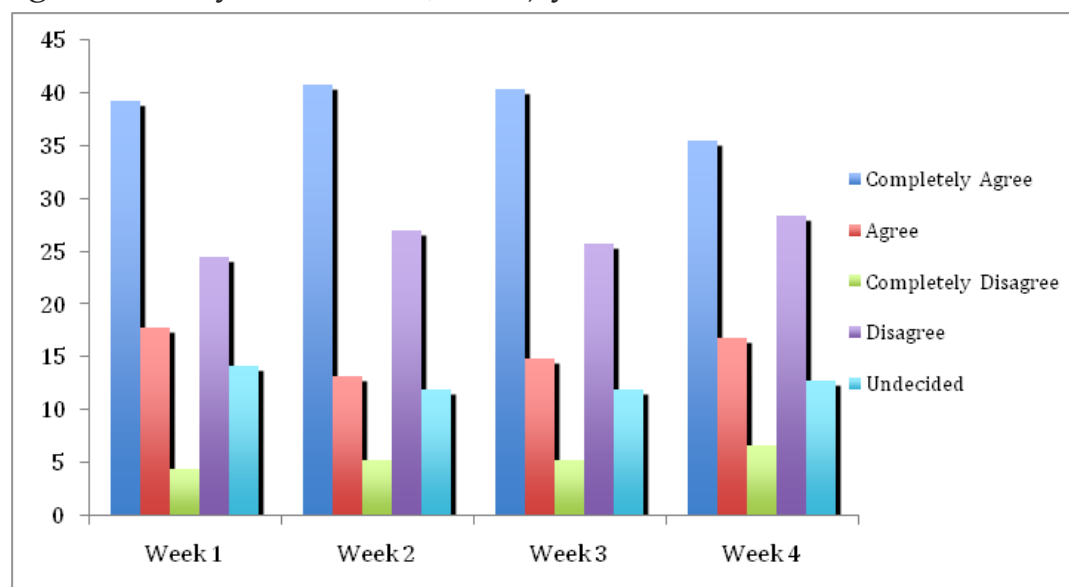

Figure 1: Question 1, Lockdown due to COVID-19 has made life boring 
A Longitudinal Study on the Psycho-Sociological Impact of COVID -19... / 113

Salesian Journal of Humanities and Social Sciences, Vol. XI, No.2 (Dec 2020) ISSN: 0976-1861 | DOI: 10.51818/SJHSS.11.2020.106-122 | Page: 106-122,

Section: Articles

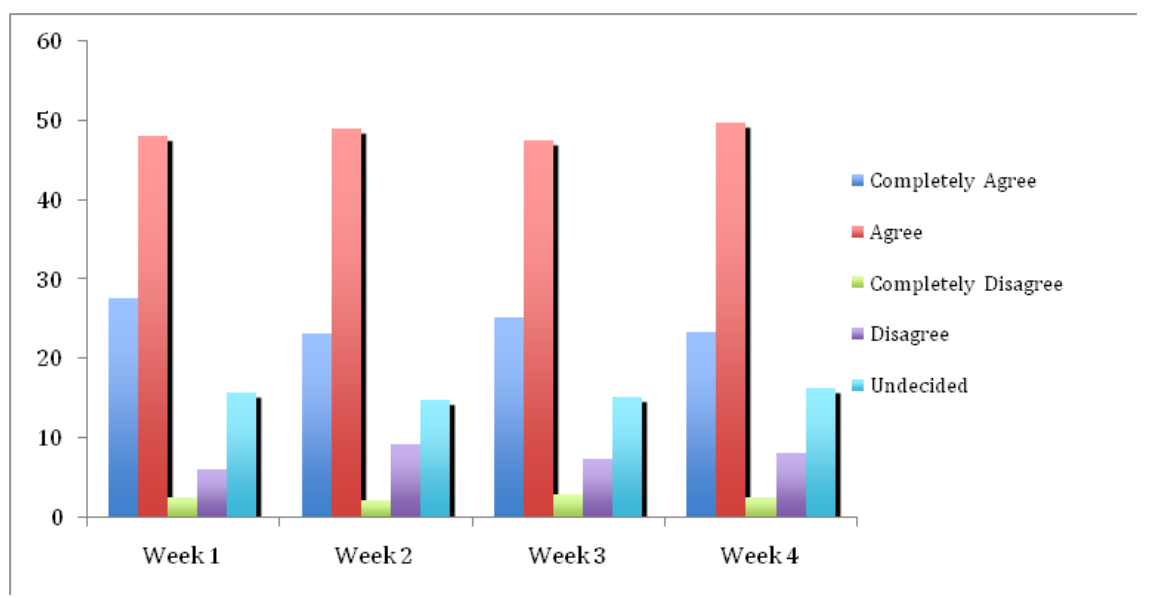

Figure 2: Question 2, I feel anxious about my family and future

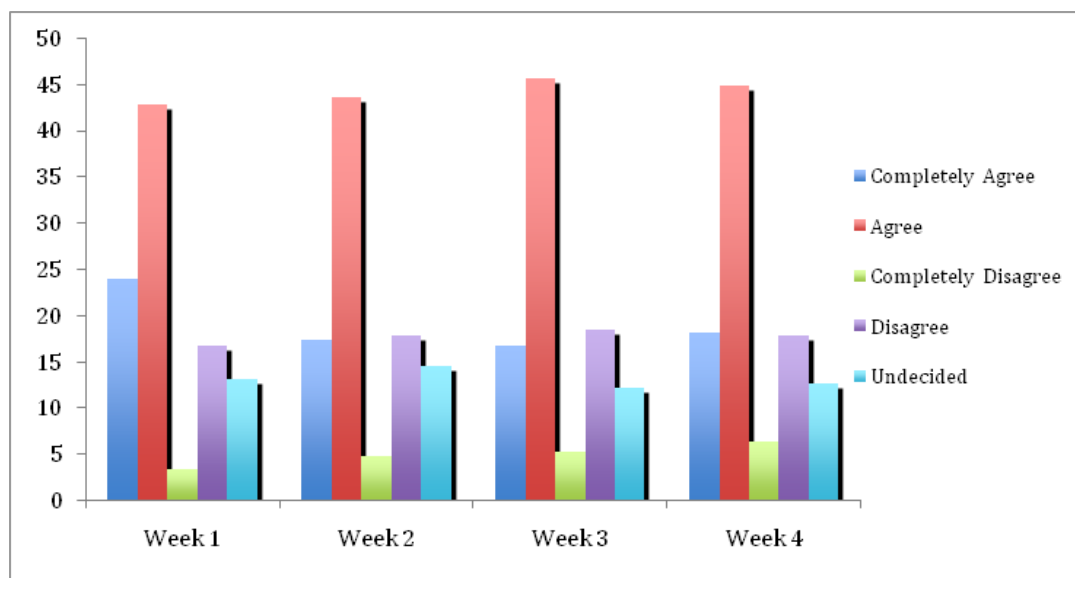

Figure 3: Question 3, Inability to meet my friends is making me very upset 
114 / Augustin Joseph, James Chacko Molekunnel, Paramita Datta, Patrick Johnson, Rachel Salomit Sitling \& Sumina Chettri

Salesian Journal of Humanities and Social Sciences, Vol. XI, No.2 (Dec 2020)

ISSN: 0976-1861 | DOI: 10.51818/SJHSS.11.2020.106-122 | Page: 106-122,

Section: Articles

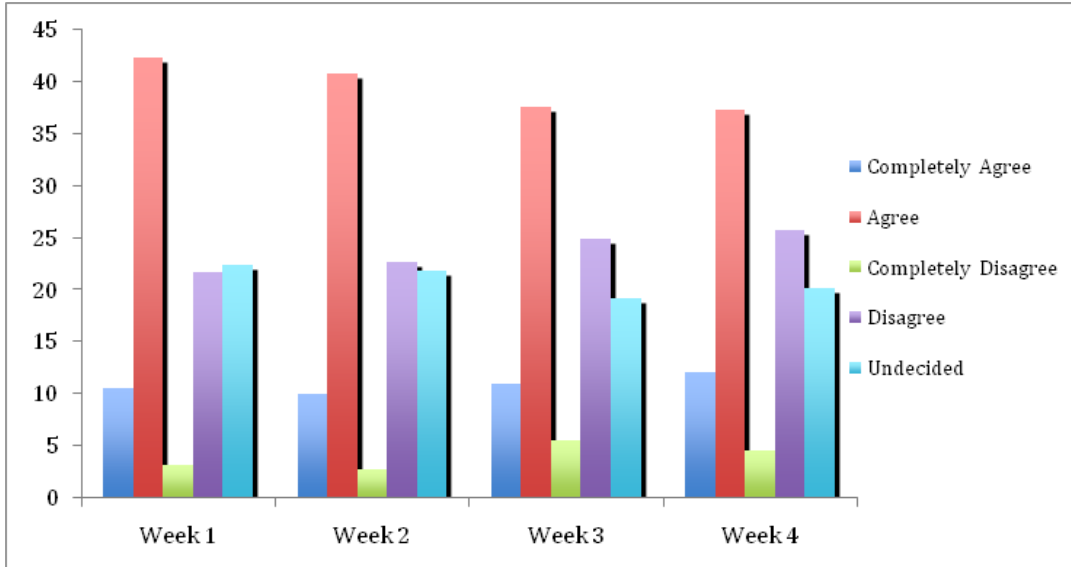

Figure 4: Question 4, Being forced to abstain from many activities I enjoyed is making me unhappy

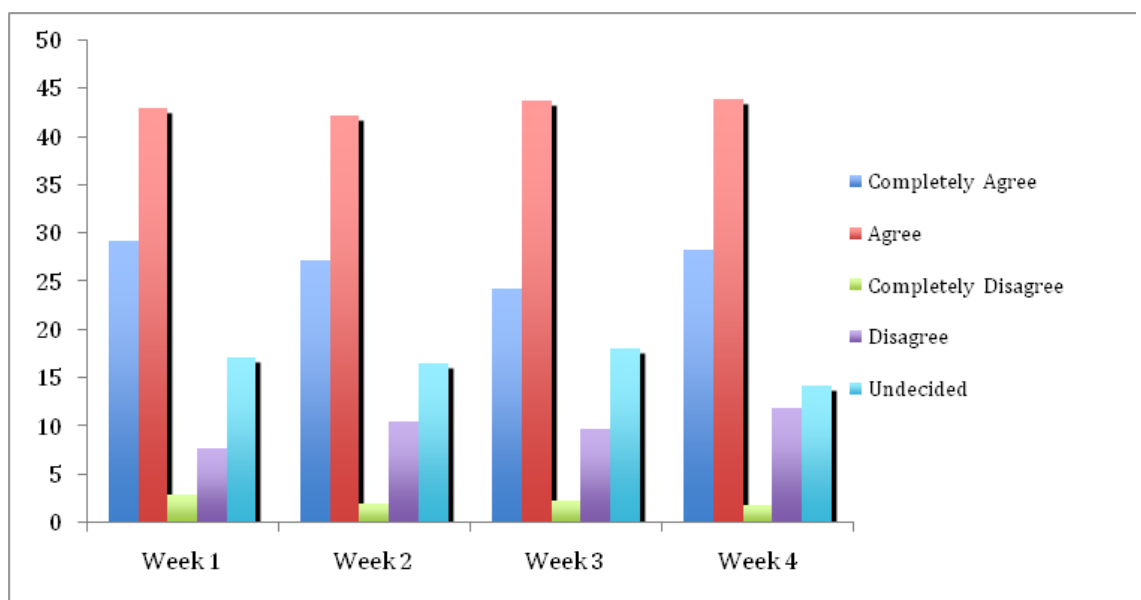

Figure 5: Question 5,I am worried about the economic impact it will have on my family 
A Longitudinal Study on the Psycho-Sociological Impact of COVID -19... / 115

Salesian Journal of Humanities and Social Sciences, Vol. XI, No.2 (Dec 2020) ISSN: 0976-1861 | DOI: 10.51818/SJHSS.11.2020.106-122 | Page: 106-122,

Section: Articles

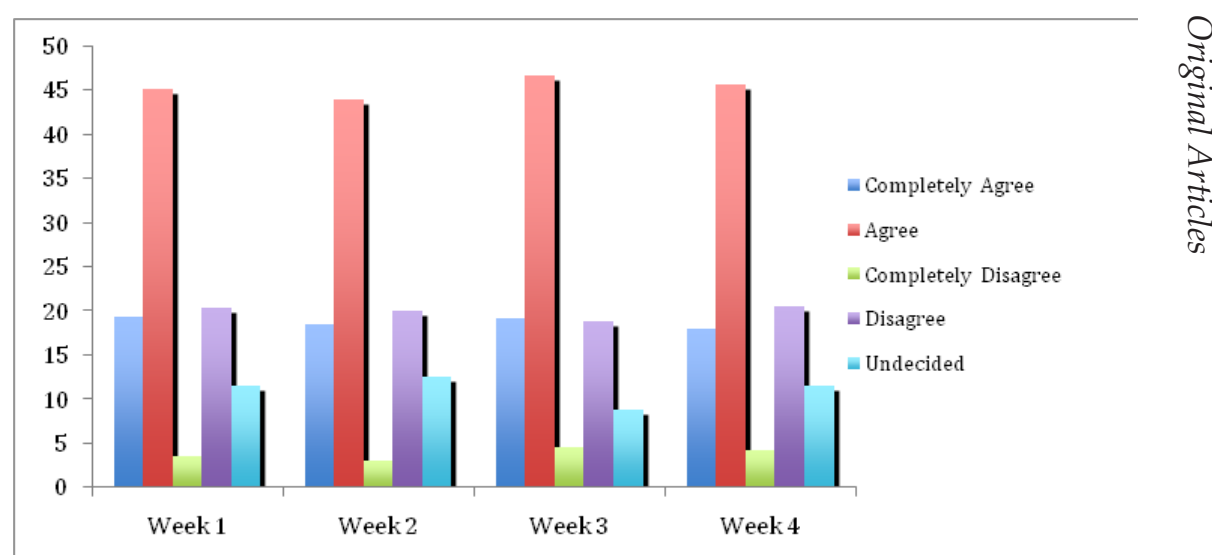

Figure 6: Question 6, COVID-19 makes me obsessed with washing hands or using hand sanitizer.

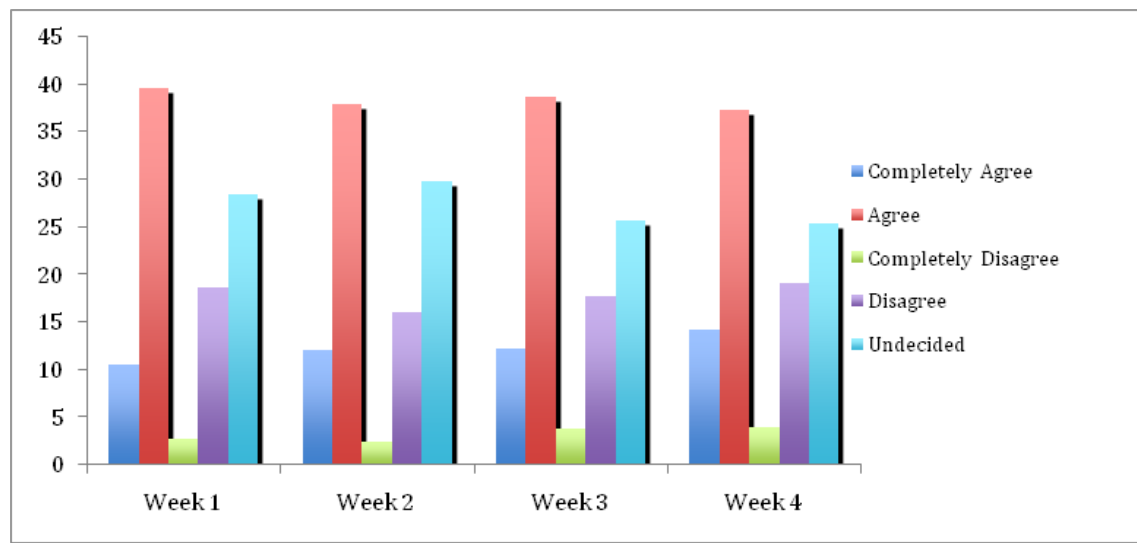

Figure 7: Question 7, I am anxious about mixing with other than family members 
116 / Augustin Joseph, James Chacko Molekunnel, Paramita Datta, Patrick Johnson, Rachel Salomit Sitling \& Sumina Chettri

Salesian Journal of Humanities and Social Sciences, Vol. XI, No.2 (Dec 2020)

ISSN: 0976-1861 | DOI: 10.51818/SJHSS.11.2020.106-122 | Page: 106-122,

Section: Articles

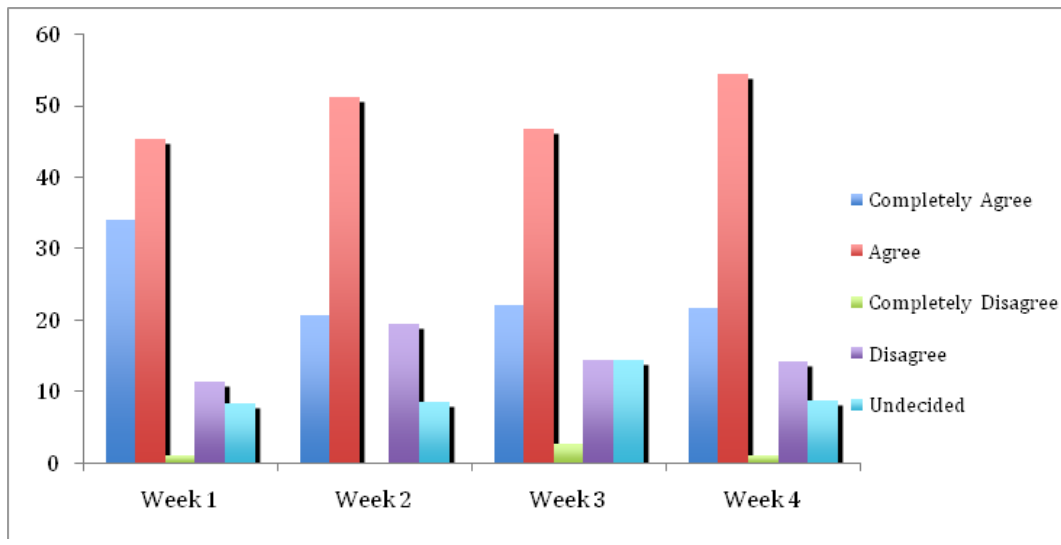

Figure 1: Question 1, I feel anxious about my family and future

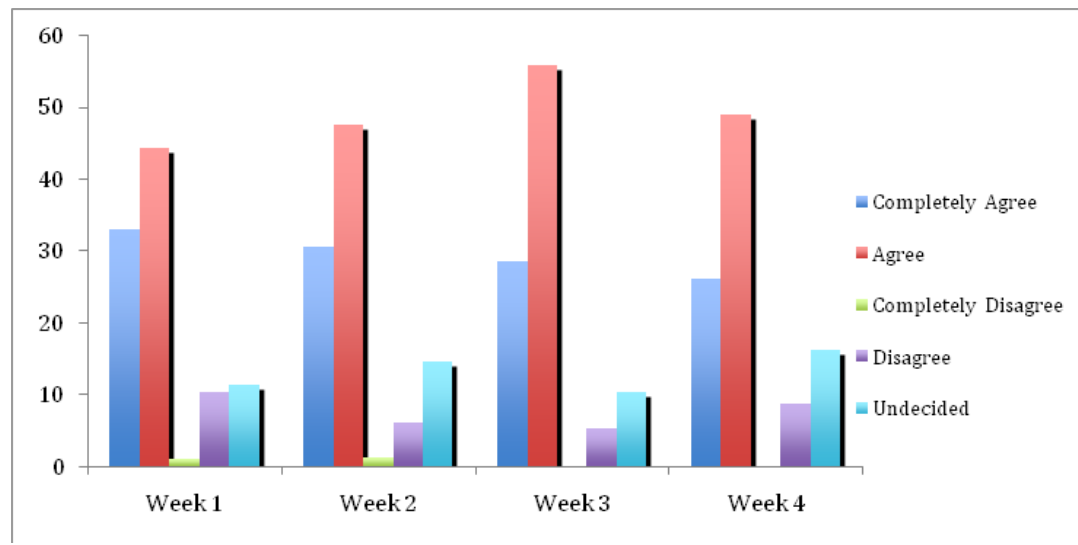

Figure 2: Question 2, I am worried about the economic impact it will have on my family 
A Longitudinal Study on the Psycho-Sociological Impact of COVID -19... / 117

Salesian Journal of Humanities and Social Sciences, Vol. XI, No.2 (Dec 2020)

ISSN: 0976-1861 | DOI: 10.51818/SJHSS.11.2020.106-122 | Page: 106-122,

Section: Articles

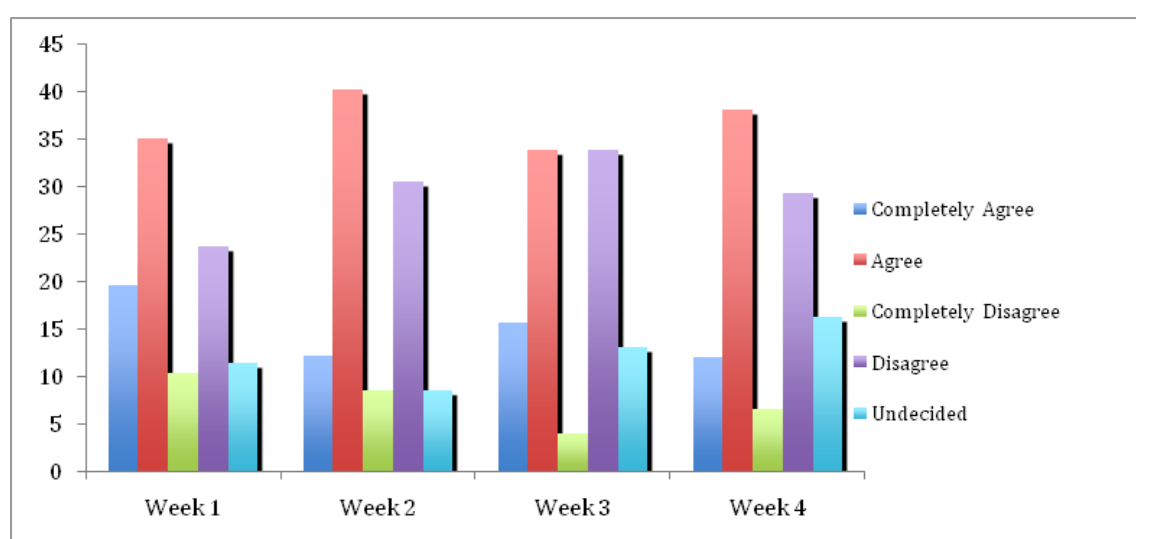

Figure 3: Question 3, COVID-19 makes me obsessed with washing hands or using hand sanitizer.

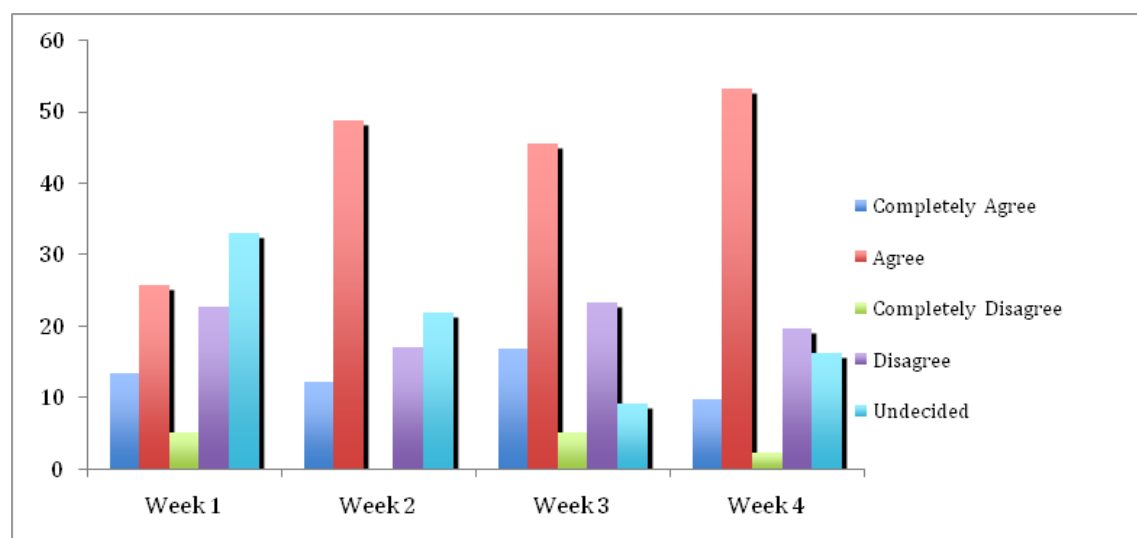

Figure 4: Question 4, I am anxious about mixing with other than family members

Majority of faculty were anxious about their family and future. Percentage of those who completely agree and agree in week 1 are $34.02 \%$ and $45.36 \%$. However as the weeks progress the figuresrecord an increase. The percentage of the faculty who agree are $51.22 \%, 46.75 \%$ and $54.3 \%$ respectively. Results also illustrate that in all the 4 weeks a major percentage of the faculty have completely agreed and agreed on being worried about economic impact of pandemic. Percentages of completely agree and agree in all of the weeks are $32.99 \%, 44.33 \% ; 30.49 \%$, 
118 / Augustin Joseph, James Chacko Molekunnel, Paramita Datta, Patrick Johnson, Rachel Salomit Sitling \& Sumina Chettri

Salesian Journal of Humanities and Social Sciences, Vol. XI, No.2 (Dec 2020)

ISSN: 0976-1861 | DOI: 10.51818/SJHSS.11.2020.106-122 | Page: 106-122,

Section: Articles

$47.56 \%$; 28.57\%, 55.84\%; and 26.09\%, 48.91\% respectively. The figures show that in each week highest percentage of participants have agreed that they are obsessed with washing hands or using hand sanitizer, i.e. $35.05 \%, 40.24 \%, 33.77 \%$ and $38.04 \%$ respectively. Majority of faculty have also agreed that they are anxious about mixing with other than family members. In week 1 percentage of completely agree and agree are $13.40 \%$ and $25.77 \%$. As the weeks progress this percentage can be seen to rise, i.e. $48.78 \%, 45.45 \%$, and $53.26 \%$ have agreed respectively.

\section{Graphical description of student data: week 1 to week 4}

\section{Graphical Description of Faculty Data: week 1 to week 4 Where Does the Pandemic Leave Us?}

The journey of life is not necessarily to be measured-neither in terms of the personal perceptions of highs and lows nor in terms of thecollective perceptions of rainbows and sunshine that appear and disappear on its horizons. Our life might apparently seem to have come to a sort of standstill due to COVID-19 pandemic. With unproven hypotheses of the nature of the impact-short term or long term - and with insufficient data to assess the situation has plunged humankind into uncertainty. Individuals - those affected and those in its vicinity - are not only battling the pandemic as a vicious threat lurking outside the self 'somewhere', but also as an invasive phenomenon with its own power to mutate and mutilate from within.

In this situation students can be seen as the most anguished as their interactions in-presence classes, sports activities and other opportunities to socialize remain restricted. The result of this study reveals that majority of students felt bored during lockdown. Boredom is an unpleasant emotional state ${ }^{15}$ and can be explained as the aversive experience of wanting, but being unable to engage in a satisfying activity. Boredom can be associated with

${ }^{15}$ S.W. Bench and H.C. Lench, "On the function of boredom", Behavioural Sciences 3, 3(2013): 459-472. https://doi : 10.3390/bs3030459. 
A Longitudinal Study on the Psycho-Sociological Impact of COVID -19... / 119

Salesian Journal of Humanities and Social Sciences, Vol. XI, No.2 (Dec 2020) ISSN: 0976-1861 | DOI: 10.51818/SJHSS.11.2020.106-122 | Page: 106-122,

Section: Articles

both low-arousal and high-arousal state. At times, boredom breeds lethargy, in other situations being bored can lead to an agitated restlessness. It is more commonly associated with negative outcomes for individuals and society, such as attention problems, reduced motivation and effort, poor performance, withdrawal from work and sometimes feeling of depression. ${ }^{16}$ Therefore, when students feel bored over a long period of time, it can hamper their mental health (sense of wellbeing) and that in turn affect their general overall performance.

It can be conclusively asserted from this study that a relatively higher percentage of students as well as faculty have concerns bordering on low to high levels of anxiety about their family (especially husband/wife, siblings and parents) and regarding their future in relation especially to economic welfare for faculty and in relation to job opportunities for students. Conditions like the present lockdown affect all aspects of life: social, economic and political in ways that intermesh and unleash aspects of coerciveness that threaten the hitherto known camaraderie of sociality. Therefore, it is natural and to an extent inevitable to become anxious.

Although the lockdown has altered the lives of many people, one cannot deny the fact that it has brought families together too. In this study most of the participants both students and faculty have agreed that they feel good about spending more time with their family. Most of the parents working from home and students taking online classes, can now spend quality time together. Simultaneously faculty who spend at least 7-8 hours in their workplace and those who were away from their homes for teaching purpose, COVID-19 has provided them opportunities to spend more time at home. However, the benefit over a long term period is yet to be ascertained, as it could unleash some dynamics of intra family co-existence that might get upset, redefining the roles and the implications and presence-absence from each other's proximity.

${ }^{16}$ Van Hooft and M. Van Hoff, "The State of boredom: Frustrating or depressing?", Motivation and Emotion 42, 6(2018): 931-946. https://doi.org/10.1007/s11031-0189710-6 
Salesian Journal of Humanities and Social Sciences, Vol. XI, No.2 (Dec 2020)

ISSN: 0976-1861 | DOI: 10.51818/SJHSS.11.2020.106-122 | Page: 106-122,

Section: Articles

Besides, the study also shows that students are unhappy because they are forced to stay at home and unable to do many activities they enjoy. In the long run they may feel upset due to this factor and it might negatively affect their performance.

Present study reveals that both the students and faculty are worried about the economic impact of the pandemic. The rise in prices as a result of the pandemic has hit everybody hard. ${ }^{17}$ During the lockdown, an estimated 14 crore (140 million) people have lost employment while salaries were cut for many others. These are but small indications of the deep economic stress in varying degrees that cannot be denied.

All the participants both students and faculty have agreed on being obsessed with washing hands and using sanitizer. Obsessive compulsive disorder are commonly viewed as germophobic and excessive cleaners who compulsively wash their hands - could be victims. The same or a similar behaviour are now encouraged in order to lower one's risk of infection and to prevent spreading of COVID-19 leaving other side effects on self and society. The fear of contamination could thus not only become an obsession but also could be the inducer for anxiety. Nonetheless, these compulsions might indeed serve to safeguard the self not merely in corporeal terms. ${ }^{18}$

MacIver opines that, "society is the web of social relationships" and that social interactions or the communication between two or more individuals act as the building blocks of society. ${ }^{19}$ While these assumptions hold good for normal times, the pandemic has

${ }^{17}$ M. Buheji et.al., "The Extent of COVID-19 Pandemic Socio-Economic Impact on Global Poverty. A Global Integrative Multidisciplinary Review", American Journal of Economics, 4(2020): 213-224.

http://journal.sapub.org/economics

${ }^{18}$ F. Aardema, "COVID-19, obsessive-compulsive disorder and invisible life forms that threaten the self", Journal of Obsessive-Compulsive and Related Disorders 26, 2020. https:// doi.org/10.1016/j.jocrd.2020.100558

${ }^{19}$ Maciver and C.H. Page, Society: An Introductory Analysis, (New Delhi: Macmillan, I 974). 
brought about unforeseen changes with the prescriptive injunctions on social-distancing for the purposes of safety. Social interaction which has always been the basis for the functioning of society has now come to a halt and people are anxious for mixing with others, they are maintaining distance from others. In the present study also majority of the participants did confirm the socially restricted mode of interactions as having come into operation in their daily routine. These newly introduced practices of social isolation and associated anxiety could eventually lead to the emergence of the feelings of loneliness in the near future.

The above summation of the present study highlights that although the pandemic brought families together, the psychological and social impact on students and faculty are more than what is immediately evident. Faculty seem better prepared to cope with the present situation with the economic fallout-long term and short term-being their major concern. The impact of lockdown is more substantial on students as they relish college life and peer association - and the very routine they had to relinquish in these times. This study clearly shows that while students have been ignoring direct questions related to depression they have been less reticent in answering the indirect questions revealing that they do suffer from anxiety and are upset. However, they are trying to cope by engaging with some activities like learning new things through internet. What surfaces from this study is that the underlying anxiety needs to be taken care of as they are vulnerable to develop psychiatric disorders like depression, and PTSD (Post Traumatic Stress Disorder).

\section{Conclusion}

By way of bringing this study and the present paper to a close we could look first, at the limitations of the study. One of the limitations of this study has been the decrease in the number of participants as the study progressed. It would have been better had there been a better consistency in the number and as regards the same 
Salesian Journal of Humanities and Social Sciences, Vol. XI, No.2 (Dec 2020)

ISSN: 0976-1861 | DOI: 10.51818/SJHSS.11.2020.106-122 | Page: 106-122,

Section: Articles

participants responding every week..$^{20}$ In not succeeding to pursue the survey-apply the same to students and faculty - for another month that would have strengthen the arguments and the datacould be considered as a limitation. This latter is indeed a limitation that can still be overcome, by restricting the survey to those who have been consistent in the first phase for all of the four weeks.

It is a fact that COVID-19 has almost turned our world upside down. We were forced to change or give up many habits we have developed during our life time and quickly adopt totally to new ways of behaviour. During this pandemic we were made aware of the need to look after our physical health but not sufficient emphasis was given to mental health as is evident from the survey. While signs of wear and tear in physical health is easily identifiable, mental health is much more difficult to spot and even more difficult to treat with all the stigma and taboos attached to it in our society. But it is essential that in this situation, people in general and students in particular give importance to looking after and promoting mental health. And the survey clearly indicates that students are more vulnerable.

${ }^{20} 24$ faculty members answered the questionnaire for all four weeks; 30 faculty members answered for three weeks and 27 answered for two weeks. 